\title{
Changes in Biological Properties of Soil through Organic and Conventional Farming at Farms of Western Madhya Pradesh, India
}

\author{
Sangeeta Dongre ${ }^{1}$, S.K. Sharma ${ }^{2}$, N.K. Jain ${ }^{3}$ and Narendra Chouhan ${ }^{2 *}$ \\ ${ }^{1}$ Govt. M.L.B. PG College, Indore (M.P.), India \\ ${ }^{2}$ Govt. Agriculture College, Indore (M.P.), India \\ ${ }^{3}$ Govt. Holker Science College, Indore (M.P.), India
}

*Corresponding author

\begin{abstract}
A B S T R A C T
Keywords

Biological properties, Soil, Organic and conventional farming

Article Info

Accepted:

15 November 2018 Available Online: 10 December 2018

Organic farming is an alternative agricultural system it is a useful farming system for the improvement of soil health and microbial properties. The experiments were conducted during 2016-17 in vertisols under the organic and inorganic farming system at farmer's field of Indore and Ujjain District. The experiments were laid out in simple randomized block design with four treatments and five replications comprised viz., $\mathrm{T}_{1}$ (Inorganic farming) $\mathrm{T}_{2}$ ( $<3$ year organic farming) $\mathrm{T}_{3}$ (3-5 year organic farming) $\mathrm{T} 4$ ( $>5$ year organic farming). There farmer's was taken as a replications. No significantly changes were found in $\mathrm{pH}$ and $\mathrm{EC}$ with irrespective of the year of organic farming practices. Organic farming significantly enhanced the organic carbon content in soil. The significantly increased the population of bacterial, fungal and actinomycetes in soil were recorded with the organic farming condition. Similarly, organic farming recorded higher soil microbial biomass carbon. Organic farming treatment $>5$ year recorded significantly higher soil biological properties followed by treatment 3-5 year organic farming, <3 year organic farming and inorganic farming.
\end{abstract}

\section{Introduction}

The role of organic agriculture is to either enhance or sustain the overall quality and health of the soil ecosystem (Ekwue, 1992). Organic agriculture is aimed at producing high quality food produce that is not only rich in nutrients but also contributes to health care and well-being of mankind. Since organic farming eliminates the use of most 'conventional' fertilizers, pesticides, animal drugs and food additives. It can improve soil, water and environmental quality and thus improve the overall quality of life. Agricultural sustainability depends on productive soil. During the last several decades, much research has focused on increasing productivity and protecting environmental quality under different farming systems. These studies shows that conventional farming use of chemical fertilizers and pesticides has increased crop yields and enhanced food security around the globe (Pang and Letey, 2000). However despite the high yields associated with it, conventional farming ability to sustain soil 
fertility and environmental quality has been called into question (Pang and Letey, 2000). Conventional farming systems are reported to be associated with a decline in soil structure and soil aggregation. A decrease in water infiltration and an increase in soil bulk density, soil salinity, nitrogen leaching and ground water contamination (McGarry et al., 2000). Tillage, climate, soil surface properties and biological activities reportedly influence the volume of transmission pores (VTP), pore structure and storage of water within the soil profile can contribute to the spatial and temporal variability of the flow domain (Hagen et al., 2002).

Agricultural practices have had an impact on soil bio-physio-chemical properties. Densities of bacteria, protozoa, nematodes, and arthropods in soils under organic farming were higher than under conventional farming (Wu et al., 2002). Organic fertility amendments enhanced beneficial soil microorganisms, reduced pathogen population, total carbon, and cation exchange capacity, and lowered down bulk densities, thus improved soil quality (Bulluck et al., 2002).

\section{Materials and Methods}

The experiments were laid out at the farmer's field located at different sites of Ujjain and Indore districts of Madhya Pradesh. Under the farming systems, three farmers were selected to characterize the soils for assessing different microbial parameters as influenced by organic farming and conventional farming systems. The organic farmers were selected based on the criteria that they have been practicing organic farming for $\mathrm{T}_{2}=<3$ year, $\mathrm{T}_{3}=3-5$ year, $\mathrm{T}_{3}=>5$ years, Inorganic farming with recommended dose of fertilizer application, replicated 5 times. The organic farming treatments where applied FYM@10t/ha. and bio fertilizers Rhizobium japonicum + PSB (for soybean) and azatobacter+ PSB (for wheat) as seed inoculants@10g per kg seed each. $\mathrm{T}_{1}=$ Inorganic farming treatments involved application of recommended doses of $\mathrm{N}: \mathrm{P}_{2} \mathrm{O}_{5}: \mathrm{K}_{2} \mathrm{O}\left(20: 60: 20 \mathrm{~kg} \mathrm{ha}^{-1}\right)$ to soybean. The popular variety of soybean JS-9305 was sown in farmer's field. The data on various parameters were recorded and statistically analysed and given in table 1 .

The soil $\mathrm{pH}$ was determined by method suggested by Piper (1967) on Glass electrode $\mathrm{pH}$ meter in 1:2 (soil: solution ratio) at $25^{\circ} \mathrm{C}$. Electrical conductivity of soil samples was determined by method suggested by Piper (1967) on conductivity meter in 1:2 (soil: solution ratio) and expressed in $\mathrm{dSm}^{-1}$ at 25 ${ }^{\circ} \mathrm{C}$. The organic carbon (\%) content of the soil samples was estimated by rapid titration method (Walkley and Black, 1934). The rhizosphere soil samples were collected at the time of crop harvesting for the analysis of population of soil fungi, bacteria, actinomycetese by standard serial dilution plate count method using agar for bacteria, (Thornton, 1922), Martin's Rose Bengal agar for fungi (Martin, 1950), Kenknight and Munair medium for actinomycetes (Wollum, 1982) and Microbial biomass carbon was determined by the fumigation extraction method with $0.5 \mathrm{M} \mathrm{K} \mathrm{SO}_{4}$ (Vance et. al., 1987)

\section{Results and Discussion}

\section{Effect of organic and conventional farming on soil pH}

The soil $\mathrm{pH}$ ranged from 7.34 to 7.20 among different fertilizer treatments after more than 5 years of conventional and organic farming (Table 1). The highest $\mathrm{pH}$ was found in the Inorganic control plots. The soil $\mathrm{pH}$ nonsignificantly decreased with application of organic matter compared to non-treated control. 
The data showed that $\mathrm{pH}$ of the surface soil were slightly decreases in the treatments were received organic matter increases over the year. There were no significantly changes in application of organic and inorganic different treatments may be due to higher buffering capacity of experimental soil (Dwivedi et al., 2007). Sheeba and Chellamuthu (2000) observed that the continued application of varying quantities of inorganic fertilizers and their combination with FYM over 22 years did not alter the $\mathrm{pH}$ appreciably. Decline in $\mathrm{pH}$ might have resulted from build-up of organic matter with time in fertilizer plots (Benbi and Brar, 2009).

\section{Effect of organic and conventional farming on soil Electrical conductivity}

The perusal of the data on Electrical conductivity of the experimental soil indicated the conventional farming or organic farming over the five year has resulted not significantly changes in soil EC (Table 1). The electrical conductivity of soil under conventional and organic farming varied from $0.65-0.49 \mathrm{dSm}^{-1}$. Further it was observed that electrical conductivity of organic soil was lower than conventional farming. The increase in the hydraulic conductivity under integrated use of NPK and FYM was mainly attributed to decrease in the bulk density and increase in the effective pore volume (Flowers and Lal, 1998) because of better aggregation in this treatment (Babu et al., 2007). similarly reported that soil EC remained almost unchanged with application of inorganic and organic fertilizer in soil.

\section{Effect of organic and conventional farming on soil organic carbon}

The response of organic manuring and fertilizer use over the 5 years are presented in Table 1. The data revealed that the lowest organic carbon content $0.31 \%$ was note in control where no organic manuring was applied. However, the organic carbon values improved significantly with proportionate increasing the year of application of organic manure in soil from $0.55-1.30 \%$. This finding appeared to be due to direct and continue application of organic matter through organic sources. Rawankar et al., (2001) and Bhandari et al., (1992) similarly finding increasing organic carbon content of soil in continues application of organic manure.

\section{Effect of organic and conventional farming on biological properties of soil}

Application of organic fertilizers recorded significantly higher populations of soil microorganisms such as bacteria, fungi and actinomycetes as compared to inorganic fertilizer application (Figs. 1a-c). The highest population of microorganism were found in the treatment were organic matter was applied for more than 5 year followed by 3-5 year, less than 3 year and inorganic treatment respectively. Fungal population (Fig. 1a) was found maximum $\left(26 \times 10^{4} \mathrm{CFU} / \mathrm{g}\right.$ soil) where organic manures were applied more than 5 year and minimum (17.96 x $10^{4} \mathrm{CFU} / \mathrm{g}$ soil $)$ was found in control plot where inorganic fertilizer was applied. A significantly variation was found in inorganic and inorganic farming.

The bacteria population and actinomycetes populations in soil under different treatments also exhibited similarly trend with minimum (26.84 x $10^{6} \mathrm{CFU} / \mathrm{g}$ soil and $18.40 \times 10^{5} \mathrm{CFU} / \mathrm{g}$ soil) and maximum (36.54 x10 6 CFU/g soil and $33.46 \times 10^{5} \mathrm{CFU} / \mathrm{g}$ soils) values were recorded in organic and inorganic treated plots (Fig. 1b-c). This might be due to application of organic content in soil which acts as a carbon and energy source of microbes. Addition of beneficial microbial inoculants to soil stimulation of soil microorganisms (ElYazeid et al., 2007). 
Table.1 Effect of organic and inorganic fertilizer application on soil chemical properties

\begin{tabular}{|c|c|c|c|}
\hline Treatments & Soil $\mathrm{pH}$ & $\mathrm{EC}\left(\mathrm{dS} \mathrm{m}^{-1}\right)$ & $\mathrm{OC}(\%)$ \\
\hline $\mathrm{T} 1$ & 7.34 & 0.65 & 0.31 \\
\hline $\mathrm{T} 2$ & 7.32 & 0.62 & 0.55 \\
\hline $\mathrm{T} 3$ & 7.28 & 0.55 & 0.79 \\
\hline T4 & 7.20 & 0.49 & 1.30 \\
\hline SEM \pm & 0.039 & 0.041 & 0.040 \\
\hline CD at 5\% & NS & NS & $\mathbf{0 . 1 2}$ \\
\hline
\end{tabular}

Fig.1 Soil biological properties influenced by application of organic and inorganic fertilizers

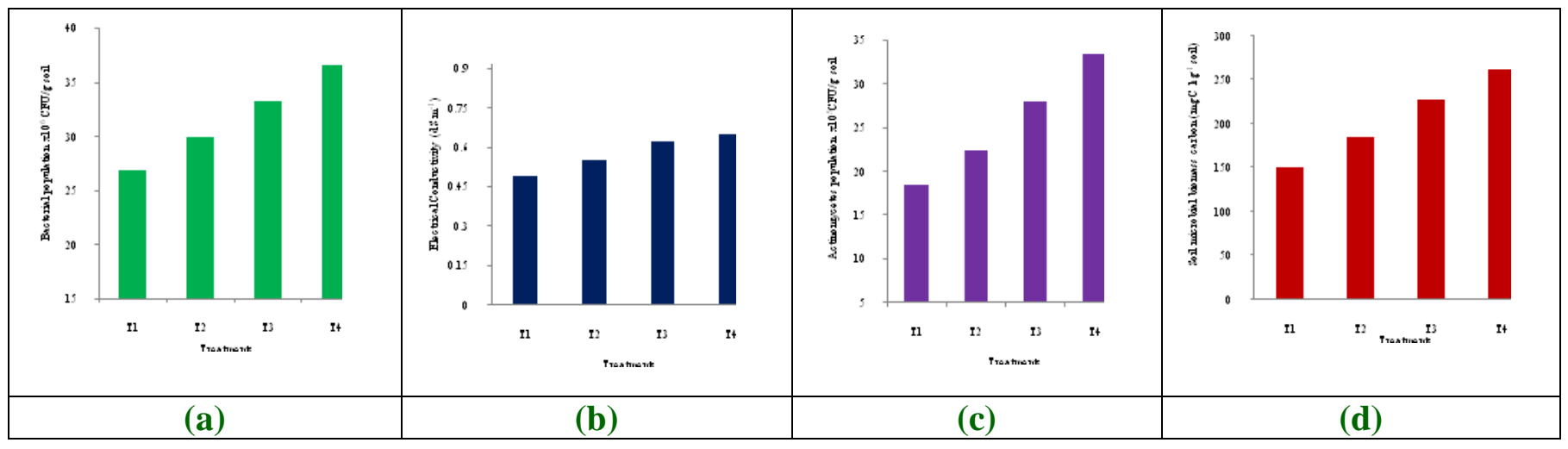

Organic applications increased nutrient status, microbial activity and productive potential of soil while the use of only chemical fertilizers in the cropping system resulted in a poor microbial activity and productive potential of soil (Kang et al., 2005).

\section{Effect of organic and conventional farming on Soil microbial Biomass of carbon}

Soil microbial biomass comprises about 2-3\% of the total organic carbon in the soil and recognized as an important source of nutrients to plants. In other words it can be defined as the concentration of microbes in the soil. It is an important indicator of soil health. The highest microbial biomass carbon $(262.36 \mathrm{mg}$ $\mathrm{C} \mathrm{kg}^{-1}$ soil) was observed in organic treated plot (organic farming > 5.0 year). This was followed by organic farming 3-5 year, organic farming $<3$ year and inorganic farming respectively (Fig. 1d). Increasing microbial biomass carbon recorded in organically treated plot might be due to suitable condition for microbial growth. A positive effect of organic fertilizer on the microbial biomass carbon in the soil was reported by Cerny et al., (2008). Increasing microbial biomass carbon in soil due to adding of organic input in soil has been well in documented in various organic substrates (Goyal et al., 1999, Chowdhary et al., 2000).

The conclusions in this study found that the application of organic matter, significantly increases the organic carbon content in soil and it gives the positive response to the soil microbial activity and soil biomass carbon in soil. However, the application of organic matter in soil increases the population of soil microbes (bacteria, fungi and actinomycetes) and soil microbial biomass carbon significantly. The chemical properties of soil $(\mathrm{pH}$ and $\mathrm{EC})$ did not affected significantly to the application of organic matter. 


\section{References}

Babu, M.V.S., Reddy, M.C., Subramanyam, A., Balaguravaih, D. 2007. Effect of integrated use of organic and inorganic fertilizers on soil properties and yield of sugarcane. J. Indian Soc. Soil Sci. 55(2):161-166.

Benbi, D.K.; Brar, J.S. 2009. A 25-year record of carbon sequestration and soil properties in intensive agriculture. Agron. Sustain. Dev., 29:257-265.

BulluckIII,L. R., Brosius, M. Evanylo, G. K. and Ristaino, J. B. 2002. Organic and synthetic fertility amendments influence soil microbial, physical and chemical properties on organic and conventional farms. Appl Soil Ecol. 19 (2):147-160.

Chowdhury M.A.H., Kouno K., Ando T., Nagaoka T. 2000. Microbial biomass, S mineralization and $\mathrm{S}$ uptake by African millet from soil amended with various composts. Soil Biol. Biochem. 32: 845852.

Dwivedi, A.K., Singh, M., Kauraw, D.L., Wanjari, R.H., Chauhan, S.S. 2007. Research bulletin on impact of fertilizer and manure use for three decades on crop productivity and sustainability and soil quality under Soybean-Wheat system on a Vertisol in Central India. IISS 224-235.

Ekwue, E.I. 1992. Effect of organic and fertilizer treatments on soil physical properties and erodibilities. Soil Tillage Res. 22 (3-4):199-209.

El-Yazeid, Abou-Aly, A.A., Mady, H.A., Moussa, M.A., S.A.M. 2007. Enhancing growth, productivity and quality of squash plants using phosphate dissolving microorganisms (bio phosphor) combined with boron foliar spray. Res. j. agric. biol. sci. 3:274-286.

Flowers, M.D., Lal, R. 1998. Axle load and tillage effects on soil physical properties and soybean grain yield on a mollic wchraqualf in northwest Ohio. Soil Tillage Res. 48: 21-35.

Goyak, S. K., chander, M. C., mundra and Kapoor, K.K. 1999. Influence of inorganic fertilizer and organic amendments on soil organic matter and soil microbial properties under tropical condition. Biol. Ferti. Soils, 29 196:200.

Hagen, E., Buczko, U., Bens, O., Brunotte, J. and Huettle, R.F. 2002. Infiltration patterns into soils under conventional and conservation tillage: influence of spatial distribution of plant root structures and soil animal activity. Soil Tillage Res. 63 (3-4):181-186.

Kang, G.S., Beri, V. O.P., Rupela and Sidhu, B.S. 2005. A new index to assess soil quality and sustainability of wheat based cropping systems. Biol. Fertil. Soils. 41: 389-398.

Martin J.P. 1950. Use of acid, rose bengal and streptomycin in the plate method for estimating soil fungi. Soil Sci. 69: 215232.

McGarry, D., Bridge, B.J. and Radford, B.J. 2000. Contrasting soil physical properties after zero and traditional tillage of an alluvial soil in the semiarid subtropics. Soil Tillage Res. 53 (2):105-115

Pang, X.P. and Letey, J. 2000. Organic farming: challenge of timing nitrogen availability to crop nitrogen requirements. Soil. Sci. Soc. Am. J. 64 (1):247-253.

Piper, C.S., 1967.Soil and Plant Analysis. Hans Publishers Bombay.

Rawankar H, Swarup, P.A., Tope, R.K., Rathod, V.B., Deshmukh, P.W. 2001. Productivity, nutrient availability and their uptake in sorghum-wheat sequence under long-term fertilizer in Vertisol. Agric. Sci. Dig. 21:141-144.

Sheeba, S. and Chellamuthu, S. 2000. Effect of long-term application of fertilizer and manures on soil properties of alluvial 
and laterite soils. Madras Agric. J. 84 (1): $15-19$.

Thornton, H.G. 1922. On the development of a standardized agar medium for counting soil bacteria with special regard to the repression of spreading colonies. Ann. Appl. Biol. 9:241-274.

Vance, E.D., Brookes, P.C., and Jenkinson, D.S. 1987. An extraction method for measuring soil microbial biomass C. Soil BioL Biochem., 19: 703-707.

Walkley, A. and C.A. Black. 1934. An examination to different method for determination soil organic matter and proposal for modification of the chromic acid titration method. Soil Sci.
37: 29-38.

Wollum, A.G. 1982. Cultural methods for soil microorganisms. In: Page AL, Miller RH, KeeneyDR, editors. Methods of soil analysis. Part. 2. Chemical and microbiological properties. Agronomy Monograph No. 9. Madison, Wis. (USA): ASA-SSSA. Pp. 781-814.

Wu,S., Ingham, E. R. and Hu, D. 2002. Soil microfloral and faunal populations in an organic ecosystem in Oregon, USA, in Proceedings of the $17^{\text {th }}$ World Congress of Soil Science. 5:1756. Queen Sirkit National Convention Centre, Bangkok, Thailand.

\section{How to cite this article:}

Sangeeta Dongre, S.K. Sharma, N.K. Jain and Narendra Chouhan. 2018. Changes in Biological Properties of Soil through Organic and Conventional Farming at Farms of Western Madhya Pradesh, India. Int.J.Curr.Microbiol.App.Sci. 7(12): 1849-1854.

doi: https://doi.org/10.20546/ijcmas.2018.712.216 